\title{
Development and Storage Study of Maize and Chickpea Based Extruded Snacks
}

\author{
Gagandeep Singh", Baljit Singh, Savita Sharma and Arashdeep Singh
}

Department of Food Science and Technology, Punjab Agricultural University,

Ludhiana-141004, Punjab, India

*Corresponding author

\section{A B S T R A C T}

\begin{tabular}{|l|}
\hline Ke y w o r d s \\
Extrusion, Maize, \\
Chickpea, Snacks, \\
Overall \\
acceptability, \\
Storage. \\
\hline Article Info \\
\hline $\begin{array}{l}\text { Accepted: } \\
\text { 29 September } 2017 \\
\text { Available Online: } \\
\text { 10 October } 2017\end{array}$ \\
\hline
\end{tabular}

\section{rds}

\section{Introduction}

Convenience foods (snack foods) have become an integral part of the daily food intake of the majority of the world's population. Properly designed convenience foods can make an important contribution to nutrition in societies where social changes are altering traditional patterns of food preparation. Basically, these are prepared from natural ingredients or components according to predesigned plans to produce products with specified quality (Limsangouan et al., 2009).

The most widely consumed extruded snacks are prepared primarily with cereals/grains due to their good expansion characteristics; however, their nutritional value is far from satisfying the needs of health-conscious consumers (Rampersad et al., 2003). Hence, there is an increasing consumer demand for more nutritious snacks (Agriculture and AgriFood Canada, 2008). Several attempts to improve the nutritional profile of extruded starch have been reported (Liu et al., 2000; Rampersad et al., 2003). Among other materials, incorporation of legume flours has been shown to cause a positive impact on levels of proteins and dietary fibre of cereal based extruded snacks (Berrios, 2006). On the other hand, addition of high-fibre, high- 
protein alternate ingredients to starch has been demonstrated to significantly affect the texture, expansion and overall acceptability of extruded snacks (Liu et al., 2000; Veronica et al., 2006). For the production of nutritious acceptable snacks, rates of starch fortification seem to vary according to the nature of each material. Legumes, for example, have been reported to cause good expansion and are regarded as highly feasible for the development of high-nutritional, low-calorie snacks (Berrios, 2006).

Maize or corn (Zea mays) is the third most important food grain after wheat and rice which belongs to the grasses family. In India, $28 \%$ maize is used for food purpose, $11 \%$ as livestock feed, $48 \%$ as poultry feed, $12 \%$ in wet milling industry and $1 \%$ as seed (AICRP 2007). On the other hand, chickpea (Cicer arietinum) is the third most important legume in the world after dry beans and dry peas. It is highly nutritious and do not contain any major anti-nutritional factors and may provide potential health benefits including reduced risk of cardiovascular disease, cancer, diabetes, osteoporosis, hypertension, gastrointestinal disorders, adrenal disease and reduction of LDL cholesterol ( $\mathrm{Hu}$ 2003; Philanto and Korhonen 2003).

Extrusion cooking technology is a hightemperature short time process that converts agricultural commodities, usually in a granular or powdered form, into fully cooked, shelf-stable food products with enhanced textural attributes and flavor. Due to the processing flexibility offered by extrusion cooking technology, it has become a cornerstone of the food industry, primarily in the cereal, dairy, bakery, confectionery and pet food industries (Patil et al., 2007). It permits preparation of ready-to-eat nutritious foods with desirable taste, flavor and texture. The importance of nutritious foods has been well recognized and several health foods has been produced and marketed in India and abroad. However, most of the proprietary nutritious foods are expensive and priced beyond the reach of the population of the middle and lower economic class. Hence preparation of low-cost nutritious foods is highly desirable and extrusion technology has been successfully applied for this purpose. Therefore the present investigation was carried out to optimize the ratio of maize and chickpea for the development of extruded snacks and to assess storage stability of prepared product.

\section{Materials and Methods}

\section{Material}

Maize (variety PMH-1) and chickpea (variety PBG 5) procured from the Department of Plant Breeding and Genetics, PAU, Ludhiana were used for the study. Salt used in final product preparation was mixture of salt (2\%). Salt procured from the local market.

\section{Physicochemical composition of raw grains}

Physico-chemical characteristics of maize and chickpea flour were determined using standard methods (AACC, 2000).

\section{Moisture content}

Weighed samples ( $2 \mathrm{~g})$ were dried in a hot air oven at $130 \pm 1{ }^{\circ} \mathrm{C}$ for $1 \mathrm{hr}$. and moisture content in percent was calculated from loss of weight.

\section{Crude protein}

Macro-kjeldhal method was used to determine nitrogen and conversion factor of 5.95 and 6.25 was used for maize and chickpea crude protein estimation. $1 \mathrm{~g}$ sample was digested in Kjeldhal flask with digestion mixture (copper sulphate and potassium sulphate in 1:9 ratio) 
and concentrated $\mathrm{H}_{2} \mathrm{SO}_{4}(20 \mathrm{ml})$ till light green colour appeared and finally cooled. Ammonia released by distillation of digested samples with saturated $\mathrm{NaOH}(80 \mathrm{ml})$ was captured in $0.1 \mathrm{~N} \mathrm{HCl}$ and percent $\mathrm{N}$ was estimated. The protein content was calculated as per cent nitrogen $\times$ factor.

\section{Crude fat}

Fat analysis of samples was carried out using Soxtec 2045 (Foss instrument, Sweden). Extraction cups were dried in oven at $130^{\circ} \mathrm{C}$ for $15 \mathrm{~min}$ and the weight of empty cups was noted. Weighed sample (3 g) was taken in thimble. Dried empty cups were cooled and $70 \mathrm{ml}$ of petroleum ether was added. Switched on and preheated the instrument, When temperature was attained, the extraction cups were attached to the instrument and left it boiling for 30 minutes, followed by rinsing for 20 minutes and last of all recovery of the solvent was done for 10 minutes. The recovered ether was collected and the fat contained in extraction cups was estimated.

\section{Ash}

Weighed (5 g) sample was first incinerated on hot plate until there were no more fumes. It was kept in a muffle furnace at $550{ }^{\circ} \mathrm{C}$ for 5 hours, weighed and results were expressed in per cent (AACC 2000).

\section{Crude fibre}

Crude fibre of maize and chickpea were estimated using Fibertec (Foss instrument, Sweden). Switch on the instrument to pre-heat the hot plate. Capsules were kept in hot air oven at $100^{\circ} \mathrm{C}$ for 20 minutes for drying. Cooled pre-weighed and noted down the weight of dried empty capsules and weighed $(1 \mathrm{~g})$ sample in capsules (Defatting of samples was done if necessary). Fixed the capsules in the rotating stand, added $250-275 \mathrm{ml}$ of 1.25 per cent $\mathrm{H}_{2} \mathrm{SO}_{4}$ to the large extraction cup and immersed the stand into the beaker. Acid extraction was done by boiling it for 30-40 minutes followed by its washing with hot water. Then alkali washing was done with 1.25 per cent $\mathrm{NaOH}$ for the same time duration followed by hot water washing. Finally, capsules were dried in oven for 2 hours at $130{ }^{\circ} \mathrm{C}$ and then placed at $550{ }^{\circ} \mathrm{C}$ for 5 hours. Cooled and weighed for crude fibre estimation (AOAC 2000).

\section{Carbohydrate}

Per cent carbohydrate was determined by subtracting other constituents. Carbohydrates $=100-($ Moisture + Protein + Fat + Ash + Fibre).

\section{Sample preparation}

Maize and chickpea was ground into flour using Lab scale super mill 3303 (Perten instrument $\mathrm{AB}$, Sweden) and passed through $200 \mu \mathrm{m}$ sieves to get a uniform size particles.

\section{Extruder and processing conditions}

Extrusion experiments were performed on a co-rotating intermeshing twin screw extruder (Clextral, Firminy, France). The barrel diameter and its length to diameter ratio (L/D) were $2.5 \mathrm{~mm}$ and 16:1, respectively. The extruder barrel is divided into four zones. Temperatures of the first, second and third zone was maintained at $40^{\circ}, 70^{\circ}$ and $100^{\circ} \mathrm{C}$ throughout the experiments, while the temperature at the fourth zone was $160^{\circ} \mathrm{C}$. The die plate had one circular hole with $6 \mathrm{~mm}$ diameter. The extruder was powered by an 8.5 $\mathrm{kw}$ motor with speeds variable from 0 to 682 rpm. 'The extruder was equipped with a torque indicator, which showed percent of torque in proportion to the current drawn by the drive motor. Raw materials were metered 
into the extruder with a single screw volumetric feeder (D S and M, Modena, Italy). The feed rate was varied for optimum fill according to screw speed. The moisture content of the feed was adjusted by injecting water (approximately $30^{\circ} \mathrm{C}$ ) into the extruder with a pump. A variable speed die face cutter with four bladed knives was used to cut the extrudates.

\section{Storage studies}

Optimized product obtained after process optimization were used for shelf-life study. HDPE (200 guage) bags were used for storage of samples at room temperature conditions over a period of 3 months and the product was evaluated for moisture content, free fatty acids, hardness, and overall acceptability, at an interval of one month, during the storage period.

\section{Free Fatty Acids}

Standard AOAC procedure (Anon 2001) was followed with slight modification. Weighed $(5 \mathrm{~g})$ sample was taken in flask. $50 \mathrm{ml}$ benzene was added and it was kept for 30 min. for extraction of free fatty acid $5 \mathrm{ml}$ extract was taken in flask, $5 \mathrm{ml}$ benzene, 10 $\mathrm{ml}$ alcohol and 2 drops of phenolphthalein solution was added and titrated against $0.02 \mathrm{~N}$ $\mathrm{KOH}$ till light pink colour disappeared.

$282 \times 0.02 \mathrm{~N} \mathrm{KOH} \times \mathrm{ml}$. of alkali used $\times$ dilution factor

FFA $($ per cent $)=$

$1000 \times$ Weight of sample taken

\section{Results and Discussion}

\section{Proximate composition of flour}

The proximate composition of raw material is given in table 1. The data given in Table 4.1 depicts the proximate chemical composition of maize and chickpea flour. Maize flour (var PMH-1) contains 9.6 per cent moisture, 1.1 per cent crude ash, 9.9 per cent crude protein, 6.8 per cent fat, 1.9 per cent crude fibre, 71.2 per cent carbohydrates. Ullah et al., (2010) reported that in maize the moisture content in the range of $9.201-10.908 \%$, ash (0.7-1.3\%), fats $(3.21-7.71 \%)$, protein $(7.71-14.60 \%)$, crude fiber $(0.80-2.32 \%)$ and carbohydrates (69.659-74.549\%). Chickpea flour (PBG 5) contains 7.9 per cent moisture, 24.2 per cent crude protein, 3.4 per cent fat, 3.5 per cent ash, 11.7 per cent crude fibre, 49.3 per cent carbohydrates. Sánchez-Vioque et al., (1999) observed that the chickpea flour contains $8.1 \pm 0.1$ moisture, $3.7 \pm 0.1$ ash, $18.8 \pm 2.0$ fibre, $24.7 \pm 1.7$ protein, $1.5 \pm 0.3$ lipids and $51.3 \pm 5.5$ carbohydrates, grams per 100 gram of dry matter.

\section{Preliminary trial}

Maize flour and chickpea were blended in the ratio of 100:0, 95:5, 90:10, 85:15, 80:20, $75: 25,70: 30,65: 35,60: 40$ and subjected to extrusion cooking at 15 per cent moisture, $500 \mathrm{rpm}$ screw speed and $160^{\circ} \mathrm{C}$ temperature. The samples were subjected to sensory evaluation. The extruded snacks were evaluated organoleptically and best combination was further used for optimization. Extruded snacks were evaluated for sensory attributes (appearance, texture, flavour and overall acceptability) through a panel of six semi-trained judges using 9-point hedonic scale (Larmond, 1970). The Table 3 depicts the sensory evaluation data of extruded snacks having different combinations of maize and chickpea level. Extruded product prepared at 80 percent of maize and 20 percent chickpea achieved best sensory score. Keeping in view the sensory quality and nutritional importance of chickpea, the blend of maize flour and chickpea flour with 80:20 ratios was selected for further study. 
Table.1 Proximate chemical composition of maize and chickpea flour

\begin{tabular}{|c|c|c|c|c|c|c|}
\hline $\begin{array}{l}\text { Types of } \\
\text { flour }\end{array}$ & $\begin{array}{l}\text { Moisture } \\
(\%)\end{array}$ & $\begin{array}{l}\text { Crude } \\
\text { protein }(\%)\end{array}$ & $\begin{array}{l}\text { Fat } \\
(\%)\end{array}$ & $\begin{array}{l}\text { Ash } \\
(\%)\end{array}$ & $\begin{array}{l}\text { Crude } \\
\text { Fibre }(\%)\end{array}$ & $\begin{array}{l}\text { Carbohydrates } \\
(\%)\end{array}$ \\
\hline Maize & 9.6 & 9.9 & 6.8 & 1.1 & 1.9 & 71.2 \\
\hline Chickpea & 7.9 & 24.2 & 3.4 & 3.5 & 11.7 & 49.3 \\
\hline
\end{tabular}

Table.2 Optimization of maize and chickpea ratio for development of snacks

\begin{tabular}{lllll}
\hline Maize: Chickpea & Appearance & Texture & Flavor & Overall Acceptability \\
\hline $100: 0$ & 8.4 & 7.8 & 8.0 & 8.06 \\
$95: 05$ & 8.2 & 7.9 & 7.8 & 7.96 \\
$90: 10$ & 8.1 & 7.9 & 7.9 & 7.96 \\
$85: 15$ & 8.0 & 7.8 & 7.9 & 7.90 \\
$80: 20$ & 8.0 & 8.0 & 7.8 & 7.93 \\
$75: 25$ & 7.8 & 7.6 & 7.7 & 7.70 \\
$70: 30$ & 7.7 & 7.4 & 7.5 & 7.53 \\
$65: 35$ & 7.7 & 7.5 & 7.0 & 7.4 \\
$60: 40$ & 7.0 & 6.0 & 7.5 & 6.83 \\
\hline
\end{tabular}

Table.3 Effect of storage period on Moisture content (\%), Free Fatty Acids (\%), Hardness and Overall Acceptability of snacks $(n=3)$

\begin{tabular}{llll}
\hline Storage period (months) & Moisture (\%) & Free Fatty Acids (\%) & Hardness (N) \\
\hline 0 & 5.80 & 0.245 & 90.7 \\
1 & 6.10 & 0.439 & 88.5 \\
2 & 6.69 & 0.572 & 84.3 \\
3 & 7.37 & 0.615 & 79.7 \\
\hline
\end{tabular}

Table.4 Effect of storage period on the sensory characteristics of extruded snacks $(n=9)$

\begin{tabular}{lllll}
\hline Storage period (months) & Appearance & Texture & Flavor & Overall Acceptability \\
\hline 0 & 8.4 & 7.8 & 8.0 & 7.66 \\
1 & 7.2 & 7.4 & 7.7 & 7.43 \\
2 & 7.1 & 7.3 & 7.8 & 7.40 \\
3 & 7.1 & 6.9 & 7.0 & 7.00 \\
\hline
\end{tabular}

Table.5 Cost of production of snacks

\begin{tabular}{|l|l|}
\hline Requirements & Cost per kg (in rupees) \\
\hline Raw material & 38 \\
\hline Milling & 08 \\
\hline Extrusion & 30 \\
\hline Packaging & 10 \\
\hline Labour & 10 \\
\hline Final cost & 96 \\
\hline \multicolumn{2}{|l}{} \\
\multicolumn{2}{|l}{4802}
\end{tabular}




\section{Storage study of snacks}

Table 3 presents the effect of storage on the moisture content, free fatty acids and hardness of snacks. An increase in moisture content was noticed after a storage period of 3 months which was obvious due to the hygroscopic nature of the snacks. Initially moisture content was 5.80 per cent, increased up to the 7.37 per cent at the end of 3 months storage. Charunuch et al., (2008) reported that there was increased in moisture content observed in Thai rice extruded snack supplemented with mulberry from 3.5 to 5 per cent during storage of 4 months and acceptability of snacks were not much affected at the $3^{\text {rd }}$ month of storage. The free fatty acids (per cent) for extruded snacks increased significantly, but remained in the acceptable range during the storage period of 3 months. The hardness of the extrudates decreased from 90.7 to $79.7 \mathrm{~N}$ after a storage period of 3 months. Charunuch et al., (2008) also reported a decrease in hardness of iron fortified extrudate Thai rice snacks from 21.38 to $19.44 \mathrm{~N}$.

Table 4 shows the sensory scores of the extruded snacks during 3 months of storage. Highest scores for appearance in extruded snacks were 8.4 which decreased to 7.1 after 3 months of storage. Similarly, texture and flavour scores were also decreased to 6.9 and 7.0 form 7.8 and 8.0 after 3 months of storage. Overall acceptability of snacks ranged from 7.00 (3 month) to 7.66. (First month) during 3 months of storage and was not much affected by 3 months of storage. Lasekan et al., (1996) observed that storage at high temperature $\left(40{ }^{\circ} \mathrm{C}\right)$ significantly reduced the sensory acceptance of the maizebased snacks.

\section{Economic evaluation}

Extruded snacks are commonly consumed by the people in India. Maize-chickpea flour blend (80:20) passed through extruder to prepare extruded snacks. Product is cheap source of balanced food. Cost includes raw material, processing and packaging expenditures (Table 5).

Maize and chickpea were blended in the ratio of 100:0, 95:5, 90:10, 85:15, 80:20, 75:25, 70:30, 65:35, 60:40 and subjected to extrusion cooking at 16 per cent moisture, $500 \mathrm{rpm}$ screw speed and $150{ }^{\circ} \mathrm{C}$ temperature. The samples were subjected to sensory evaluation. The extruded snacks were evaluated organoleptically and best combination (80:20) was used for further study. It may be concluded that the incorporation of chickpea at $20 \%$ level for the preparation of extruded snack food showed an acceptable sensory scores. Storage slightly affected the overall acceptability of snacks. During the entire 3 months of storage, overall acceptability of snacks was within acceptable range. During the first month of storage snacks had moisture content and free fatty acid content values were 5.88 and 0.242 , which increased to 7.18 and 0.603 respectively, whereas the hardness and overall acceptability of snacks, decreased from 90.7 and 7.66 to 79.7 and 7.00 respectively at the end of 3 months storage.

\section{References}

AACC, 2000. Approved Methods of American Association of Cereal Chemists. $10^{\text {th }} \mathrm{Ed}$. The Association St. Paul, MN.

Agriculture and Agri-Food Canada, 2008. The Canadian snack food industry. http://www4.agr.gc.ca/AAFCAAC/displ ayafficher.do?id=1172692863066\&lang =eng Accessed 22.10.2008.

AICRP, 2007. Biology of maize. Department of biotechnology. Ministry of Sci. and Tech. Govt of India.

AOAC, 2000. Official Methods of Analysis. Association of official analytical chemists, Washington, D C $14^{\text {th }}$ Ed. 
Berrios, J., De J, Morales P, Camara M and Sanchez-Mata M C 2010. Carbohydrate composition of raw and extruded pulse flours. Food Res Int 43: 531-36.

Charunuch, C., Tangkanakul, P, Rungchang S and Sonted V 2008. Application of mulberry (Morus alba L.) for supplementing antioxidant activity in extruded Thai rice snack. Kasetsart $J$ (Nat Sci) 42: 1-9.

Hu, F.B., 2003. Plant based foods and prevention of cardiovascular disease: An overview. American J Clinic Nutr 78: 544-51.

Larmond, E., 1970. Methods for Sensory Evaluation of Food. Canada Department of Agriculture Pubn 1284.

Lasekan, O.O., Lasekan W, Idowu M A and Ojo O A 1996. Effect of extrusion cooking conditions on the nutritional value, storage stability and sensory characteristics of a maize- based snack food. J Cereal Sci 24: 75-89.

Limsangouan, N., Takenaka M, Sotome I, Nanayama $\mathrm{K}$, Charunuch $\mathrm{C}$ and Isobe $\mathrm{S}$ 2009. Functional properties of cereal and legume based extruded snack. Food fortified with by- products from Herbs and Vegetables. Kasetsart J. (Nat. Sci.) 44: $271-79$.

Liu, Y., Hsieh F, Heymann H and Huff H E 2000. Effect of process conditions on the physical and sensory properties of extruded oat-corn puff. J Food Sci 65: 1253-59.

Patil, R.T., Berrios J A G and Swansons B G 2007. Evaluation of methods for expansion properties of legume extrudates. Applied Engg Agric 23: 77783.

Philanto, A., and Korhonen H 2003. Bioactive peptides and proteins. Adv Food Nutr Res 47: 175-81.

Rampersad, R., Badrie, N. and Comissiong, E 2003. Characteristics of Flavored Snacks from Extruded Cassava/Pigeonpea Flour. J Food Sci 68:363-67.

SaÂnchez-Vioque, R., Clemente A, Vioque J, Bautista J, MillaÂn F 1999. Protein isolates from chickpea (Cicer arietinum L.): chemical composition, functional properties and protein characterization. Food Chem 64:23-243.

Ullah, I., Ali M and Farooqi A 2010. Chemical and nutritional properties of some maize (Zea mays.) varieties grown in nwfp, Pakistan. Pakistan J Nutr 9: 1113-17.

Veronica, O., Olusola, O, Adebowale, E., 2006. Qualities of extruded puffed snacks from maize/soybean mixture. $J$ Food Process Engg 29:149-61.

\section{How to cite this article:}

Gagandeep Singh, Baljit Singh, Savita Sharma and Arashdeep Singh. 2017. Development and Storage Study of Maize and Chickpea Based Extruded Snacks. Int.J.Curr.Microbiol.App.Sci. 6(10): 4798-4804. doi: https://doi.org/10.20546/ijcmas.2017.610.447 